\title{
Understanding the Factors that Influence Students' Behavior: Key Towards an Effective Teaching
}

\author{
Milky Mae D. Bandera1, Januard D. Dagdag² \\ 12 Isabela State University - Roxas, Philippines \\ * e-mail: januard.d.dagdag@isu.edu.ph
}

\begin{abstract}
The main duty of a teacher is teaching. But in fact, teachers do many things. Aside from relaying the information that their students need to learn, they are also responsible for handling students with different characteristics and behaviors. Thus, it is a problem if teachers do not know how to facilitate them as well as if they do not have enough understanding of educational psychology. Knowing and understanding the cause of students' different behaviors is one way for teachers to facilitate their students appropriately and teach effectively. This article then discusses salient factors that lead to reasons why students behave in such ways. It also emphasizes how a teacher will become effective in teaching if they learn the root of students' behavior.
\end{abstract}

Keywords: Understanding; factors; behavior; effective teaching

How to cite : Dagdag, J., \& Mae D. Bandera, M. (2021). Understanding the Factors that Influence Students' Behavior: Key towards an Effective Teaching. Pedagogi: Jurnal Ilmu Pendidikan, 21(2), 144-148. https://doi.org/https://doi.org/10.24036/pedagogi.v21i2.1182

Leenses may copy, distribute, display and perform the work an make derivative and remixes based on it only if they
give the author or licensor the credits (attributtion) in the manner specified by these. Licensees may copy, distribute,
display, and perform the work and make derivative works and remixes based on it only for non-commercial purposes

INTRODUCTION

Teachers deal with many students everyday. It is given that no student is identical in characteristics, behaviors, opinions, and views. Students vary regarding physical, intellectual, social-emotional, moral, spiritual, and cultural background (Darsih, 2018). It is true that aside from teaching the lessons everyday, it is also a struggle for teachers to handle hundreds of students in a day. Indeed, it is not easy. It can be said that relaying the lessons to the students is not the mere responsibility of a teacher.

The 21 st century has truly demanded teachers to acquire enough skills, knowledge and values to carry out their duties and responsibilities as teachers. They are also required to become globally competitive professionals for "they are the key players in ensuring high quality education skills and career preparedness for all young people" (Ngislawan, 2020).

Furthermore, the rise of modern technologies pushed the field of teaching to upgrade its methodologies and ways to provide the best education for the students. Thus, teachers were required to hone their skills and widen their knowledge as it became the utmost priority to be able to go with the advent of rolling time (Tadas, 2019). In line with this, teachers are seen to be the "role model" of the society. No doubt that they make a huge impact to everyone especially on the students. However, this opportunity comes with many challenges.

One challenge for them is to how they will address the lesson with hundreds of students with different characteristics and views. Not all students are similar when it comes in welcoming new ideas from their instructor. In other words not all approaches, methods, and techniques used by the teacher fit every student. One way to avoid this dilemma is by knowing the students well. This is one reason why teachers study human development during their college years. Studying human 
development can teach a great deal about learners as well as it will help teachers to gain insights into how learners behave, think, learn and feel. Digging deeper into what factors affect their behaviors and development is also a big help to conquer the challenge that teachers are facing.

In relation to this, this article discusses the identified significant predictors on students'/learners' behavior and development from different literatures which affect their approach towards education. At the end, this article states how understanding salient predictors of students' behavior and development leads to successful and effective teaching.

\section{DISCUSSIONS}

Report says that 40 percent of teachers identified that students who poorly excel in academics and have problems in behaviors are seen to be some of the barriers why teachers cannot teach effectively (Morin, 2020). This article section therefore discusses significant predictors leading to why it happens. Such factors identified were school, family, peer pressure, community, and media/technology.

\section{Family}

Family is the smallest unit of the society. It is also the first place where students learn many things. Therefore, parents have the largest role in raising their children. Thus, playing their key role has an impact as their child begins to attend school. According to David Wilkerson in 2005 as cited by (Sanjay, 2012) good parents do not always produce good children, but devoted, dedicated, hardworking mothers, and fathers can weigh the balance in favor decency and the building of moral character. Furthermore, every word/deed of a parent is a fiber woven into the character of a child which ultimately determines how that child fits into the fabric of society (Sanjay, 2012). Studies also prove that parent involvement in child's education does not only enhance academic performance but also has a positive influence on his attitude and behavior (Pangilinan, 2012). However, not all students behave in a typical way where it should be decent like what he learns from his home. Instead, not all families have perfect connections, and it affects how a student deals with many things inside the school. Some students have difficulty in socializing and connecting to other people. They have difficulties in expressing their thoughts and feelings whenever they are inside the school. It can be observed that these kinds of students tend to develop behavior problems and sometimes affect their academic performance. These observations may linked to negligence and abuse of family members, exposure to parental criminal activities and behaviors, acts of violence, availability and use of dangerous weapons and drugs at home, or even divorce or remarriage of either parent (Belle, 2017).

Moreover, research says that socio-economic status (SES) of a family attributes to the behavior of an adolescent [student]. It has been found that there is a moderate positive relationship between parental SES and the adolescents' academic performance and behavior (Khaliq, Baig, Ameen, \& Mirza, 2016). Students from low SES tend to have greater academic stress and behavior problem than those from high SES (Sonali, 2017). In view of this, research confirms that students are more disruptive in school when they came from a broader economic inequality and social distance (Arum \& Ford, 2012). Therefore, it can be gleaned that teachers should show fairness and equality in all of their students, whatever their economic status, to avoid negative psychological and emotional effects that later would adversely affect their studies.

\section{School}

Schools are the nurseries of the state and where students spend most of their time everyday. It is no denial that learning institution has a great impact to a student's behavior. In fact, the characteristics of the school may impact on the ways in which the students behave with others (Belle, 2017). In relation to this, researchers found the school features that encourage students to misbehave. These include overpopulated learning environment; violent discipline measures from school heads; incompetent school administrators and faculties; lack of freedom to choose on what to learn; discrimination; poor connection from friends, educators, and school heads; too much focus on academic excellence where extracurricular activities for the development students in other aspects are limited; and absence of support for students who 
struggle in academic and those who have behavioral problems (Belle, 2017). Students who experience any of these factors tend to feel depression and isolation more than other peers in which the level of anger aggression heighten in their behavior (Shehzadi, 2017) which affect their academic performance and impression towards learning. Low self-esteem and self-confidence are also linked with these factors.

On the same hand, researchers pointed out educators as one of the factors that lead learners to misbehave (Belle, 2017). Students may show unnecessary behaviors and attitudes if they see their instructor teaches ineffectively in the class, if they feel that they are not cared, if they do not receive academic feedback and guidance, if they observe their to have low communication skills, if she attends the class late on time, does use mobile phone during the class, ineffective leadership inside the classroom and many more.

On the contrary, teachers' expertise and knowledge of students can help them notice and interpret student behavior (Hofkins \& Ruzek, 2019). It can be seen from the way teachers address assessments. Articles say that assessment can be beneficial to a learner or not. Students lose their motivation if they see the assessments too challenging while other students see these as an effective way to improve their academic performance. Spending most of the time with the whole class correlates with better outcomes in attendance, behavior, and academic achievement rather than with individual pupils (Dworkin, 2009). He added that there is also a positive impact among students' behavior when teachers focus on teaching the subject and lesson compared to when they merely focus in organizing or disciplining the class or distributing materials.

\section{Peer Pressure}

Peer of students can serve as a good or bad influence to them. The behavior that a student portrays reflects on who his companions are. Besides, the peer group pressure influences what the adolescent values, knows, wears, eats and learns (Lukman \& Hamadi, 2010). In other words, growing adolescents take up their peers at school as their role models as their parents are no more considered as role models to them (Belle, 2017). So, it is important to choose peers who can benefit him in all aspects including his behavior towards learning. Sometimes, students who are not choosy of their companion, especially if they choose those who badly influence them, tend to fail. For instance, instead of concentrating to study for the upcoming examination, a learner is encouraged to go with his friends and get along with them doing unimportant things. As a result he will get a low score in the exam.

Meanwhile, peers can make students feel unsecured with regards to their social status. It can also increase the level of their stress or for worst can lose their motivation in education. On the other hand, some students working with others in doing their activities in the class see it more effective for them to become productive in the class (Silva, 2020).

\section{Community}

Aside from family, the community also plays a large role in a learner's behavior towards education. There is a significant positive correlation between school, family, and community involvement and student success (Henderson \& Mapp, 2002). Though teachers are seen to be the partners of parents in inculcating values, community's responsibility is also essential because even before a child enters the school, the community is the first environment that he is exposed to. What he shows in the school is a reflection of what he learned from his community. Then if a student is aggressive inside the class, it might show that the community is disorganized. Otherwise, a student will act decently inside the class. According to a recent policy brief from the National Education Association (NEA), teachers', parents' and community's collaboration and cooperation help in students' academic performance (Pride Surveys, 2016). Students tend to have positive approach towards education which results to having higher grades, regular attendance, longer stay in school, and enroll in higher level of education. 


\section{Media/Technology}

With the advent of technology nowadays, students are easily influenced by it. Given that it is the most widely used platform to relay information in this time of pandemic, students are really technology driven. However the use of technology to access media (Social Media) also has a negative effect on a student. Technology and media may be used as a means of bullying, sexting and other risks. Involved students can suffer from psychological problems that affect their performance in the class. In addition, the mass media easily inculcate unnecessary behavior and practices among adolescent students that they can imitate such as violence and immorality (Ngwokabuenui, 2015). There is a tendency for them to adopt and for worst can bring them into the classroom setting.

\section{CONCLUSION}

Teaching profession is about inspiring and motivating students to realize and exceed their potentials. It is the responsibility of teachers to "build every [students'] national morality" as well as their character, and skills by setting up a situation in which they will learn effectively. Furthermore, the effective teacher has the ability to make students better and improve if they have to. On the contrary, the ineffective teacher adversely affects the learning of both good and the not so good student.

The teachers should take note on students' characteristics to help them learn optimally. Hence, determining the factors that affect the students' behavior is helpful for teachers to teach effectively. Knowledge and ability to incorporate ideas to the class are not enough to benefit students. A teacher can easily relay information for their students and responds to what they really need. In addition, having a good relationship with the parents of students will also lessen the problem that a teacher will carry. They are the partners of teachers together with the community to address solutions to the challenges that students face regarding unnecessary behaviors towards learning. To conclude, there are many ways on how to become an effective teacher but understanding students' cause of behavior is one of the foundations leading to an effective way of teaching.

\section{REFERENCES}

Belle, L. . (2017). Factors that Influence Student Behaviour in Secondary Schools. European Journal of Educational Development Psychology, 5(5), 27-36.

Darsih, E. (2018). Learner-Centered Teaching: What Wakes It Effective. Indonesian EFL Journal, 4(1), 35-37. https://doi.org/10.25134/ieflj.v4il.796

Dworkin, P. (2009). School as Mileu Student Behavior : an Overview.

Henderson, A. T., \& Mapp, K. L. (2002). A New Wave of Evidence: The Impact of School, Family, and Community Connections on Student Achievement. Annual Synthesis.

Hofkins, T., \& Ruzek, E. (2019). Measuring Student Engagement to Inform Effective Interventions in Schools. Student Behavior : an Overview.

Lukman, A. A., \& Hamadi, A. A. (2010). Disciplinary Measures in Nigerian Senior Secondary Schools: Issues and Prospects. IOSR Journal of Research and Method in Education, 4(3), $11-17$.

Morin, A. (2020). Understanding Behavior as Communication: A Teacher's Guide.

Ngislawan, C. (2020). The Teaching Profession: Elements, Meaning and its Historical Development in the Philippines.

Ngwokabuenui, P. Y. (2015). Students' indisicipline: Types, Causes and Possible Solutions: The Case of Secondary Schools in Cameron. Journal of Education and Practice, 6(22), 64-73.

Pangilinan, I. E. (2012). Role of Parental Involvement in Education. The Modern Teacher, 61(7), 252.

Sanjay, F. M. (2012). Influence of Parents in Improving the Subject Ratings of Grade Three Pupils of Piddig District. The Modern Teacher, 61(7), 254.

Shehzadi, N. (2017). Factors Affecting the Child's Personality. Medium.

Silva, V. (2020). 8 Factors that Affect Students' Motivation in Education. Built by Me. 
Surveys, P. (2016). Why Community Involvement in School is Important. Pride Surveys. Tadas, P. (2019). Teachers Challenges: The Challenges Faced by a Teacher. 